\title{
ПРОБЛЕМИ ЗАБЕЗПЕЧЕННЯ ЗБЕРЕЖЕННЯ ІНВЕНТАРНОГО ПАРКУ НАПІВВАГОНІВ В ЕКСПЛУАТАЦІї
}

\section{PROBLEMS SECURING INVENTORY PARK OPEN WAGONS IN OPERATION}

\author{
Представив д-р техн. наук, професор І.Е. Мартинов
}

Постановка проблеми. В результаті виведення 3 експлуатації рухомого складу, який відпрацював призначені терміни служби, за останні 15 років парк вантажних вагонів скоротився на 120 тис. од. Знос рухомого складу, термін експлуатації якого становить 20-25 років, перевищує $81 \%$. Найбільш гостродефіцитними вантажними вагонами є напіввагони, середній ступінь зносу яких складає 80 \%, і в період з 2012 по 2020 роки за терміном служби підлягають вилученню 3 інвентарного парку ще близько 40 тис. одиниць, при наявному парку 58 тис. одиниць.

Мета статті. Аналіз стану інвентарного парку напіввагонів, виявлення причин прискореного зносу і виведення 3 експлуатації напіввагонів, які не відпрацювали призначені терміни служби.

Аналіз останніх досліджень. Питанням збереження вагонів при вантажнорозвантажувальних роботах, а також дослідженням пошкоджень кузовів напіввагонів в експлуатації присвячені праці Сендерова Г.К., Лосева П.Р., Другаля С.А. [1], Головка В.Ф., Візняка Р.І. [2] та ін. В цих роботах було закцентовано увагу на комплексному дослідженні причин масових пошкоджень напіввагонів в експлуатації.

В рамках даної статті пропонується провести аналіз існуючого стану українського парку напіввагонів і виявити недоліки, які перешкоджають забезпеченню збереження напіввагонів. 
Викладення основного матеріалу статті. За даними Головного управління вагонного господарства Укрзалізниці, для забезпечення потреб залізниці у перевезенні вантажів універсальними напіввагонами, потрібно утримувати наявний інвентарний парк на рівні приблизно 65 тис. од. (за даними статистики 2012 року). 3 урахуванням парку напіввагонів, що знаходяться у власності приватних компаній (більше 30 тис. од.), вважається, що цього було б достатньо для щодобового навантаження більше 1,2 млн т вантажів.

Загальний парк напіввагонів (див. рисунок) за попередні більш ніж 15 років постійно змінювався, так, ще у 1994 році він складав близько 120 тис. од. (з яких 112,4 тис. од. належало Укрзалізниці і лише 7,4 тис. од. - приватним компаніям). У 2012 році парк Укрзалізниці налічував вже 58,2 тис. од., в той час, коли приватним компаніям належало 32 тис. напіввагонів.

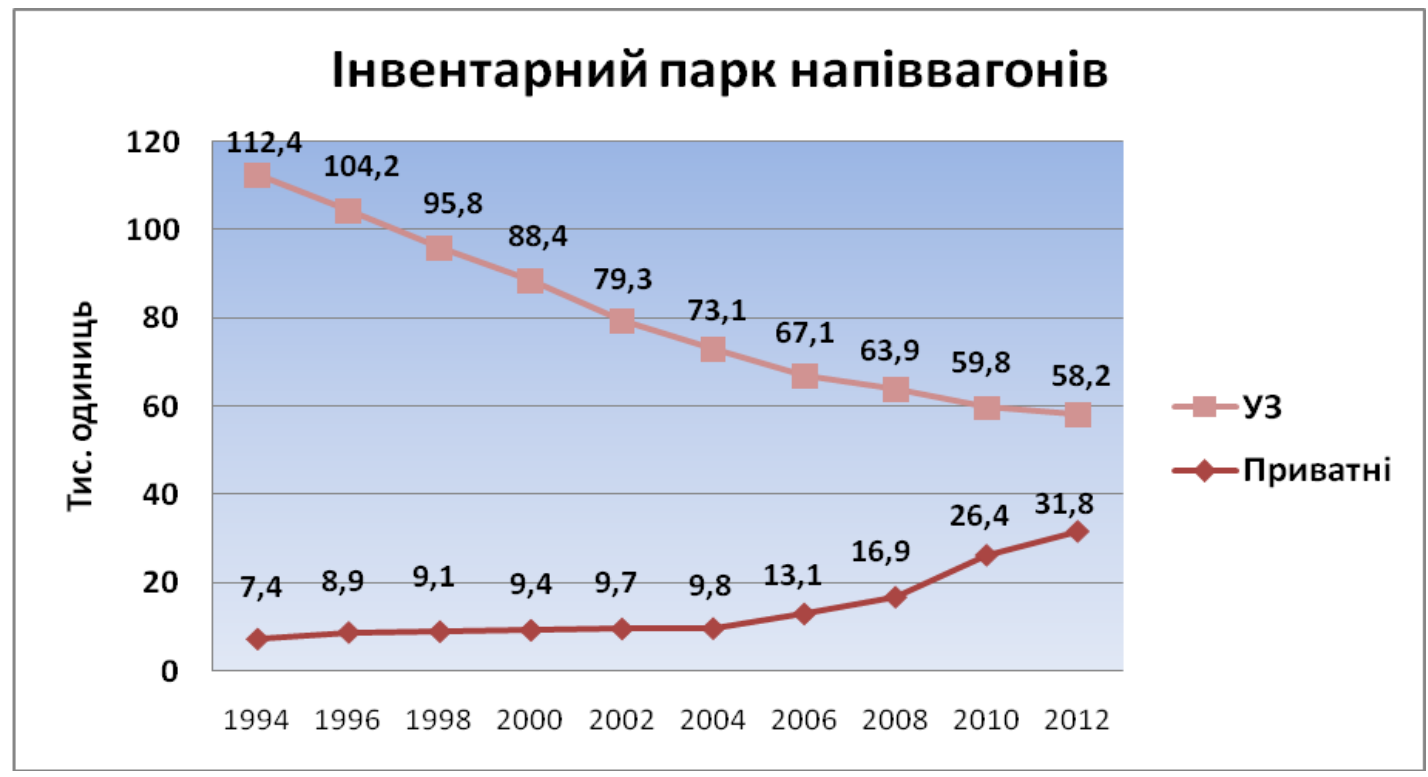

Рис. Інвентарний парк напіввагонів (31994 по 2012 рр.)

Тенденції до зменшення кількості інвентарного парку залишалися, частка ДП «Укрзалізниця» поступово знижувалася до майже $60 \%$, а частка приватного парку збільшувалась до $40 \%$.

На теперішній час ступінь зносу напіввагонів досягає 80 \% і в період з 2012 по 2020 роки за терміном служби підлягають вилученню 3 інвентарного парку більше 40 тис. од., при наявному парку 58 тис. од. Середньодобовий дефіцит напіввагонів становить більше 5 тис. од. За розрахунками спеціалістів Головного управління вагонного господарства Укрзалізниці для розв'язання проблеми дефіциту вантажного рухомого складу необхідно негайно закупити не менше 8 тис. напів- вагонів, в той час, коли зараз в середньому закупається близько 1 тис. од. на рік.

Зменшення кількості одиниць робочого парку напіввагонів пов'язане 3 погіршенням технічного стану, а також невиконанням плану 3 придбання вагонів згідно 3 «Комплексною програмою оновлення залізничного рухомого складу України на 2008-2020 роки» та програмою «Український вагон». Несвоєчасне оновлення парку рухомого складу може призвести до непередбачуваних наслідків для економіки держави. До критичної межі наближається й інфраструктура залізниці, яка до 1991 року забезпечувала майже вдвічі більші обсяги перевезень і ще має резервні пропускні спроможності, але в 
цілому залізнична транспортна система застаріла і значною мірою вже не в змозі задовольняти потреби держави у вантажних перевезеннях.

Поповнення парку за рахунок нових вагонів залишається досить проблематичним питанням. Тому останніми роками значна увага приділяється виявленню причин прискореного зносу і виведення 3 експлуатації напіввагонів, які не відпрацювали призначені терміни служби.

Пошкодження вагонів - це результат порушення технічних умов вантажних операцій, правил експлуатації у процесі маневрової та поїзної роботи та використання застарілих агресивних технологій при виконанні вантажнорозвантажувальних робіт на різних промислових підприємствах, гірничометалургійних комплексах i, особливо, у морських та річкових портах.

Так, за 2012 рік допущено більше 6 тис. випадків пошкодження вантажних вагонів, у тому числі у портах України сталося понад 1300 випадків пошкоджень, що складає майже $25 \%$ від їх загальної кількості.

При цьому в середньому за добу 3 технічних несправностей відчіплювалися близько 1400 напіввагонів. Основною їх причиною $є$ порушення технічних умов при вивантаженні вагонів 3 використанням грейферних кранів, які щоденно використовуються у більшості портів України (Одеський, Южний, Іллічівський, Керченський та інші МТП).

Внаслідок збільшення швидкості опускання грейфера на вантаж, зчеплення ковшем підлоги, стінок кузова пошкоджуються перекриття, внутрішні елементи конструкції вагона та люки, які складають близько 80 \% площі підлоги. Матеріально-технічні бази портів не забезпечують своєчасний ремонт та планові профілактичні роботи 3 утримання в належному стані засобів вивантаження.

Усі пошкоджені вагони потребують проведення позапланових ремонтів, для їх відновлення Укрзалізниці доводиться спрямовувати додаткові кошти. До того ж напіввагон при цьому «випадає» 3 перевізного процесу, що тим самим викликає збільшення дефіциту напіввагонів під завантаження. Також суттєво погіршує цю ситуацію те, що власники не надають свої вагони під грейферне вивантаження.

Укрзалізниця постійно вживає заходів iз забезпечення вагонного парку. Зокрема, на залізниці було направлено телеграму щодо встановлення 3 лютого по березень місячника жорсткого контролю за вивантаженням сипких вантажів із напіввагонів власності Укрзалізниці (особливо грейферними кранами) на всіх місцях виконання таких вантажних операцій, у тому числі у портах 3 метою підвищення рівня відповідальності під час виконання вантажних операцій.

Слід нагадати, що вантажні вагони тепер не у власності держадміністрації, якою $\epsilon$ Укрзалізниця, a у власності держпідприємств. В рамках реформи Укрзалізниця створила ДП “Український логістичний транспортний центр", а також почала процес передачі вагонів на баланс кількох державних компаній. Зокрема напіввагони, яких в Україні більшість, передали до двох держкомпаній "Укрспецвагон" (Український державний центр 3 експлуатації спеціалізованих вагонів) та “Дарницький вагоноремонтний завод”. Вважається, що дане нововведення покращить ситуацію щодо забезпечення збереження рухомого складу.

Укрзалізниця i приватні власники наполягають i надалі наполягатимуть на більш активному використанні в портах вагоноперекидачів, але зараз таке обладнання $є$ тільки у двох держпортах Маріупольському та Південному. А переробку сипучих вантажів, таких як руда, вугілля, залізорудний концентрат здійснюють також такі порти, як Іллічівський, Керченський, Миколаївський, Одеський та ін. Установлення вагоноперекидачів вимагає значних фінансових 
ресурсів, стабільного вантажопотоку, а також зміни технології роботи порту. Їх будівництво має бути економічно обгрунтовано для даного порту. У більшості випадків більш економічно вигідним $\epsilon$ будівництво підвищених колій (естакад) для вивантаження вагонів через люки.

Також для своєчасного забезпечення портів вагонами та ремонту незначних пошкоджень кузовів вагонів пропонується створення на території портів пунктів ремонту вагонів. Це може дати можливість збільшення пропускної спроможності портів з обробки сипучих вантажів, частка яких у загальному вантажному обороті портів складає майже $50 \%$. При цьому значно зменшиться час «випадіння» вагонів 3 перевізного процесу та поліпшаться умови безпеки робітників.

За даними Укрморрічфлоту, у зв'язку 3 розвитком передових технологій розвантаження

вагонів

портами заплановано придбання універсальних гідравлічних кранів-маніпуляторів, що практично не ушкоджують вагони під час вивантаження, дозволяючи портам однаково працювати як з експортними, так і з імпортними вантажами.

I, звичайно ж, першим пунктом вирішення проблеми пошкоджень рухомого складу стає звичайне дотримання технологій навантажувальнорозвантажувальних робіт.

Аналізуючи вищенаведене, можна зробити висновок, що використання розглянутих способів розвантаження напіввагонів, як першочергова альтернатива грейферам, дозволить значно подовжити життя вітчизняному рухомому складу. А в сукупності з оновленням парку напіввагонів вагонами нового покоління, значно зменшить їх дефіцит.

\section{Сиисок літератури}

1. Сендеров, Г.К. Сохранность вагонов при погрузочно-разгрузочных и маневровых работах [Текст] / Г.К. Сендеров, П.Р. Лосев, С.А. Другаль. - М.: Транспорт, 1984. - 155 с.

2. Головко В.Ф., Нові технічні системи розвантаження нанапіввагонів [Текст] / В.Ф. Головко, Р.І. Візняк // Інформаційно-керуючі системи на залізничному транспорті. 2002. - № 6. -С. 25-27.

3. Петров, А. «Хромающие» вагоны [Текст] / А. Петров // Порты Украины. - 2010. № 10 (декабрь). - С. 45-48.

4. Укрзалізниця проводить місячник посиленого контролю за дотриманням технології вивантаження вагонів [Електронний ресурс] // Урядовий портал. - Режим доступу: http://www.kmu.gov.ua/control/publish/article?art_id=246100689

Ключові слова: інвентарний парк, напіввагон, знос.

\section{Анотації}

Розглянуті проблеми виведення з експлуатації рухомого складу, який відпрацював призначені терміни служби. Докладно проаналізовано стан інвентарного парку напіввагонів, виявленно причини їх прискореного зносу i виявлено недоліки, які перешкоджають забезпеченню збереження напіввагонів.

Рассмотрены проблемы вывода из эксплуатации подвижного состава, отработавшего положенные сроки службы. Подробно проанализировано состояние инвентарного парка полувагонов, выявлены причины их ускоренного износа и недостатки, которые препятствуют обеспечению сохранности полувагонов. 
Збірник наукових праць Української державної академії залізничного транспорту

The problems decommissioning of rolling stock, completed the period of service. Detailed analyzes of inventory park open wagons, identifying the causes of accelerated wear and reveal deficiencies that hamper the preservation of open wagons. 